\title{
Citation Analysis of Library and Information Science (LIS) Research Output for Collection Development
}

\author{
Sureni Weerasinghe ${ }^{1}$
}

\begin{abstract}
The purpose of this paper was to provide useful indicators for library LIS collection development in order to better serve its user community. Core journals utilized by LIS academic researchers in Sri Lanka were identified via the application of Bradford's law of scattering to the Journal of the University Librarians Association (JULA) of Sri Lanka. This study analyzes 46 articles containing 803 citations, published in the open access Journal of the University Librarians Association (JULA) during 2010-2015. The most cited format was determined, and a ranked list of core journals was prepared employing the Bradford's law. Journals were revealed to be the most frequently cited format, which accounted for $51.31 \%$ of all citations. Data sets were fit with the Leimkuhler model of the Bradford's law. Thirteen journals were identified as belonging to the most productive nucleus of journals cited by articles in the Journal of the University Librarians Association (JULA). In the ranked list of core journals, "The Journal of Academic Librarianship" was ranked as first. The chronological distribution of cited material revealed that LIS researchers had mostly used materials published within 2001-2010 time period. Further, the categorization of articles into subject domains within LIS showed that most studies were conducted within the field of "information seeking". This paper provides useful insights for librarians in LIS collection development of libraries in Sri Lanka.
\end{abstract}

Keywords: Bradford's Law, Sri Lanka, Citation Analysis, Leimkuhler, Core Journals, Collection Development.

\footnotetext{
${ }^{1}$ Assistant Librarian, University of Peradeniya. Email: sureniw@pdn.ac.lk

(iD) http://orcid.org/0000-0001-7337-8408
} 


\section{Introduction}

The term "bibliometrics" was introduced in 1969 by Alan Pritchard as "the application of mathematics and statistical methods to books and other media of communications" (Pritchard, 1969, p. 349). Bibliometric approaches can be employed to satisfy various objectives including, assessment of research output, developing scientific indicators, journal selection and predicting a field's potential (Zafrunnisha, 2012). "Citation analysis is a branch of bibliometrics that examines the citations found in publications such as journal articles and books to look for patterns of use" (Hoffmann \& Doucette, 2012, p. 321). This technique is extensively used to determine the most significant journals in a field. According to Wardikar (2013), in any subject stream there are journals which researchers frequently cite due to the link between their work and the literature in those journals. These are "core journals" of a particular field and "always contain a higher concentration of relevant articles" in that field (Sudhier, 2010, p.03). It is important that librarians include these journals into their library collections. Librarians face the challenge of making decisions on material selection and cancellation concerning the library collection due to the increasing cost of material and lack of space. Mainly, effective decisions on journal subscriptions against the limited finances must be made. Citation analysis is a valuable means that supports librarians to make such decisions regarding collection development. The libraries in Sri Lanka including academic libraries need to enhance and update their LIS collections to provide an improved user service. For instance, the LIS collection in the Main Library of University of Peradeniya which is a special collection within the Main Library collection needs to be updated. This collection was started around 1960 and has been continuously developed till around 2000. But currently it is not being frequently updated and the collection lacks of current scholarly information on library and information science. In making collection development policies it is vital for librarians to be aware of the resource needs of their user category. For collection management, documents that are cited more frequently are the more important and valuable ones that must be included into the library collection. The main user group of library LIS collections in Sri Lanka is the Sri Lankan academic librarians who engage in research as part of their profession. This study aims to provide insights for LIS collection 
development in Sri Lankan libraries via analyzing the research output produced by Sri Lankan academic librarians.

For the purpose of the study the Journal of the University Librarians Association (JULA) of Sri Lanka was selected because it is very popular among Sri Lankan academic librarians and it opens great avenues for Sri Lankan LIS researchers to publish their research. The Journal of the University Librarians Association (JULA) of Sri Lanka is a double-blind, peer-reviewed journal published by the University Librarians Association of Sri Lanka (ISSN: 1391-4081). This is a biannual open access journal which can be accessed via the Sri Lanka Journals Online (SLJOL) database (http://jula.sljol.info/).

The objectives of the current research were to:

- determine the most preferred format of citation

- identify the core journals utilized by LIS researchers in Sri Lanka

- testify the Bradford's law of scattering

- identify the chronological distribution of cited material

- categorize the articles into subject domains in LIS

- make suggestions for LIS collection development

\section{Literature Review}

Citation analysis has been used as a collection development tool in various disciplines. Literature reveals many citation studies conducted using students' theses or dissertations on a particular field with the purpose of developing a user-centric library collection.

Barnett-Ellis \& Tang (2016) conducted a citation analysis with the focus of developing a user-centered collection. They analyzed 2351 citations, revealed from 40 master level biology theses. The results showed that the most cited format were journals, accounting for $75 \%$ and $10 \%$ were for books while $15 \%$ constituted government documents, websites, dissertations and theses (Barnett-Ellis \& Tang, 2016). Based on the results they made recommendations for "future collection development and library instruction practices" (Barnett-Ellis \& Tang, 2016). Similar studies were conducted by 
Banateppanvar, Biradar \& Kannappanavar (2013) and Trigar, Abolghasemi \& Yaminfrooz (2013) in different disciplines but they all observed that journals were the most preferred format of citation.

Banateppanvar et al., (2013) analyzed citations of doctoral theses in Biotechnology which were submitted to Kuvempu University, Karnataka. They identified that journals $(79.72 \%)$ were the most popular information source among biotechnology scholars. Bradford's law of scattering was applied to the journal citations. Further, their examination of authorship pattern of cited material revealed that more contributions were made by multi authors with 0.8 degree of collaboration. Trigar et al., (2013) conformed to this study by revealing that journals were the most preferred format in their study of graduate dental theses of medical science.

In the Sri Lankan context, Angammana, \& Jayatissa (2016) conducted a bibliometric study of 70 postgraduate LIS theses that were submitted for the Master in Library Science (MLS) of the University of Colombo and Master in Social Science in LIS (MSSc) of the University of Kelaniya. A total of 4901 citations were analyzed. However this study disagrees with the similar study of Chikate \& Patil (2008), conducted in the Indian context. Angammana \& Jayatissa (2016) found that Sri Lankan post graduate students widely utilized books which accounted for $39 \%$ of citations. They applied Bradford's law in order to determine the core journals and College and Research Libraries journal was ranked first. Contrastingly, in their study based on LIS dissertations, Chikate \& Patil (2008) identified that nearly half of the citations were from journals (42.2 per cent) while books, web, reference books, proceedings, reports, theses, newspapers, interviews, pamphlets and manuscripts were also referred.

In the field of Sociology, citation studies have revealed contradictory results in comparison with results of similar studies in other fields. Gunasekera (2014) analyzed citations of 12 Sociology Masters Theses of University of Peradeniya which were submitted during 1995-2012. It was revealed that $56 \%$ of total citations were monographs, succeeded by journals that accounted for $22 \%$. Rozenburg (2015) also gained similar results in his study of Sociology and Anthropology graduate students theses and dissertations of 
Hebrew University of Jerusalem. Singh \& Bebi (2013) analyzed 5766 citations of 25 Sociology $\mathrm{PhD}$ theses that were submitted to the Department of Sociology of University of Delhi during 1995-2010. They found that single authored $(83.94 \%)$ citations were the highest in number and that majority $(67.23 \%)$ of the citations came from books while only $22.2 \%$ of citations were from journals. It shows that sociology researchers prefer to cite books more than journals and this result is different compared with results of similar studies in other fields that found journals as the most preferred format of citation.

Other than student theses, journals were also widely used for analyzing citations in order to identify general and specific trends in a field. Banateppanavar, Dharanikumar \& Vindya (2015) examined the citations extracted from articles published in the Collection Building journal from 2009-2012. The authors found that journals (53.84 per cent) were the most popular format cited by LIS researchers. In the list of ranked journals Collection Building was ranked first with 68 citations (9.70 per cent). Further, data sets were fit well with Bradford's law of scattering. Similar studies were carried out by Simisaye \& Osinaike (2010) and Kuri \& Hajje (2014). Simisaye \& Osinaike (2010) analyzed articles in the Journal of Library and Information Science (JOLIS) from 2004-2009, while Kuri \& Hajje (2014) examined articles in Pearl: A Journal of Library and Information Science during the time period of 2009-2011.Both studies observed journals as the most frequently cited format. In the ranked lists, African Journal of Library, Archives \& Information Science topped the list in the former study, while Annals in Library and Information Studies came first in the latter.

The literature reveals several bibliometric studies conducted by researchers using journal articles, within the Sri Lankan context. Navaneethakrishnan \& Kupesan (2015) conducted a bibliometric analysis of the Sri Lanka Journal of the Humanities which was published by the University of Peradeniya, Sri Lanka. A total of 319 articles, authored by 147 authors during the period 1975 - 2009 were analyzed in this study. The authors found that "distributions of publications vary over the period of study" and that "research growth of publications increased with positive indicators" 
(Navaneethakrishnan \& Kupesan, 2015, p.51). In a related study, Gunasekera (2008), analyzed 141 LIS articles, published in 1997-2007, extracted from two Sri Lankan LIS journals: the Journal of the University Librarians Association (JULA) and the Sri Lanka Library Review. This study revealed that majority of the articles (94\%) was single authored. The researcher asserted that Sri Lankan LIS research output seemed to be condensed in the domains of "LIS Activities" and "Information Seeking" and that Sri Lankan LIS researchers tend to conduct more survey type of studies (Gunasekera, 2008).

Citation analysis studies must be continuously conducted because with time there may be various changes and developments in scholarly output. According to the literature, there is a lack of attempts that focus on enhancing the LIS collection development of Sri Lankan university libraries via identifying the current trends in the LIS research output during the time period of 2010-2015. This study hopes to fill this gap and extend the body of knowledge in the field of citation analysis in the Sri Lankan context.

\section{Methodology}

The articles published in the Journal of the University librarians Association (JULA) of Sri Lanka, during the time period 2010-2015 were selected for the study. The required data were extracted via the SLJOL database. The reference list of each article was examined and the information was categorized to align with the objectives in a table using MS excel spreadsheets. This study employed only full length research articles while book reviews, commentaries and editorials were excluded. Citations were divided into seven major categories: journals, books, proceedings, theses and dissertations, web resources, reports (technical reports) and miscellaneous (government documents, circulars, standards, handbooks, newspapers, magazines, course materials).

This is a quantitative study performed on 46 articles that revealed 803 citations. The journal citations were organized in their descending order of frequency. The core journals were identified by the application of the Bradford's law of scattering. 


\section{Application of Bradford's law}

Bradford's law of scattering demonstrates the quantitative relationship between journals and the articles published in those journals (Sudhier, 2010). This is a popular tool which is widely utilized in studying the journal productivity of a certain field. Journals are arranged according to the descending order of their productivity and will be divided into three zones that are approximately equal. Bradford defined the first zone as "nuclear zone" and the second zone as moderately productive whereas the third zone was defined as the low productive zone. The "nuclear zone" is highly productive and accounts for a small number of core journals. Observing regularity in computing the title number in each zone, Bradford concluded that "the ratio of the titles in successive zones followed a common pattern" (Sudhier, 2010, p. 05).

Bradford demonstrated his law of scattering as:

[. . . ] if scientific journals are arranged of decreasing productivity of articles on a given subject, they may be divided into a nucleus of periodicals more particularly devoted to the subject and several groups or zones containing the same number of articles as the nucleus, when the numbers of periodicals in the nucleus and succeeding zones will be as 1: $\mathrm{n}: \mathrm{n}^{2}$ [. . .] (Bradford, 1950, p. 116).

Based on Bradford's law, several authors including Brookes, Vickery and Leimkuhler formulated different models in order to describe the scattering phenomena (Sudhier, 2010). Leimkuhler (1980) formulated a model basing Bradford's verbal formulation:

$\mathrm{R}(\mathrm{r})=\mathrm{a} \log (1+\mathrm{br}), \mathrm{r}=1,2,3, \ldots$

$\mathrm{R}(\mathrm{r})$ is the cumulative number of items produced by sources of rank 1,2,3, . , $r$.

$\mathrm{a}$ and $\mathrm{b}$ are constants that appear in the Leimkuhler's law.

While explaining Leimkuhler's Law, Egghe (1985, 1990a, 1990b) has shown:

$\mathrm{A}=\mathrm{Y}_{\mathrm{o}} / \log \mathrm{K}$

$\mathrm{b}=(\mathrm{k}-1) / \mathrm{r}_{\mathrm{o}}$ 
Where $r_{o}$ is the number of sources in the first Bradford's group, $Y_{o}$ represents the number of items in every Bradford group (all these groups of items being of equal size) and $\mathrm{k}$ is the Bradford multiplier.

Egghe (1986) has derived a mathematical formula for calculating k. His formula is based on the fact that if journals are ranked in their decreasing order of productivity, $\mathrm{Y}_{\mathrm{m}}$ is the number of items in the most productive source (i.e. the source of rank one). $p$ is number of groups and this is shown as a parameter that can be freely chosen when forming Bradford's groups. Once $\mathrm{p}$ and $\mathrm{Y}_{\mathrm{m}}$ are determined $\mathrm{k}$ can be calculated by:

$$
\mathrm{k}=\left(\mathrm{e}^{\gamma} \mathrm{Y}_{\mathrm{m}}\right)^{1 / \mathrm{p}}
$$

Where $\gamma$ is Euler's number

$\gamma=0.5772$ and $\mathrm{e}^{\gamma}=1.781$

Then, $\mathrm{k}=\left(1.781 \mathrm{Y}_{\mathrm{m}}\right)^{1 / \mathrm{p}}$

Also $\mathrm{Y}_{0}$ and $\mathrm{r}_{\mathrm{o}}$ follows:

$\mathrm{Y}_{\mathrm{o}}=\mathrm{Y}_{\mathrm{m}}^{2} \log \mathrm{k}$

and

$\mathrm{r}_{\mathrm{o}}=(\mathrm{k}-1) \mathrm{Y}_{\mathrm{m}}$

According to Egghe (1990b) the formulas (6) and (7) have limited application because $Y_{o}$ and $r_{o}$ can be deduced easily using practical data. Furthermore, Egghe (1990a, 1990b) has shown:

$Y_{0}=A / p$, where $A$ indicates the total number of articles in the bibliography.

Let $\mathrm{T}$ represents total number of sources or journals. In the $\mathrm{i}^{\text {th }}$ Bradford group, there are $r_{0} k^{i-1}$ sources $(i=1,2,3, \ldots p)$. Therefore,

$\mathrm{T}=\mathrm{r}_{\mathrm{o}}+\mathrm{r}_{\mathrm{o}} \mathrm{k}+\mathrm{r}_{\mathrm{o}} \mathrm{k}^{2}+\ldots .+\mathrm{r}_{\mathrm{o}} \mathrm{k}^{\mathrm{p}-1}$

So, $\mathrm{r}_{\mathrm{o}}=\mathrm{T} /\left(1+\mathrm{k}+\mathrm{k}^{2}+\ldots+\mathrm{k}^{\mathrm{r}-1}\right)=\mathrm{T}(\mathrm{k}-1) /\left(\mathrm{k}^{\mathrm{p}}{ }_{-}\right)$

Since $\mathrm{A}$ and $\mathrm{T}$ can be known from the raw data, $\mathrm{r}_{\mathrm{o}}$ and $\mathrm{Y}_{\mathrm{o}}$ are computed once $\mathrm{k}$ is calculated using equation (5).

\section{Results and Discussion}

The study examined 803 citations that were revealed from 46 articles published in the Journal of the University librarians Association (JULA) during the period 2010-2015. The distribution of the format of cited material is summarized in Figure 1. It shows that journals are the most preferred format of citation, accounting for $51.31 \%$ of total citations. This result 
agrees with many previous studies (Banateppanvar et al., 2013; Trigar et al., 2013; Chikate \& Patil, 2008; Kuri \& Hajje, 2014) of similar type.

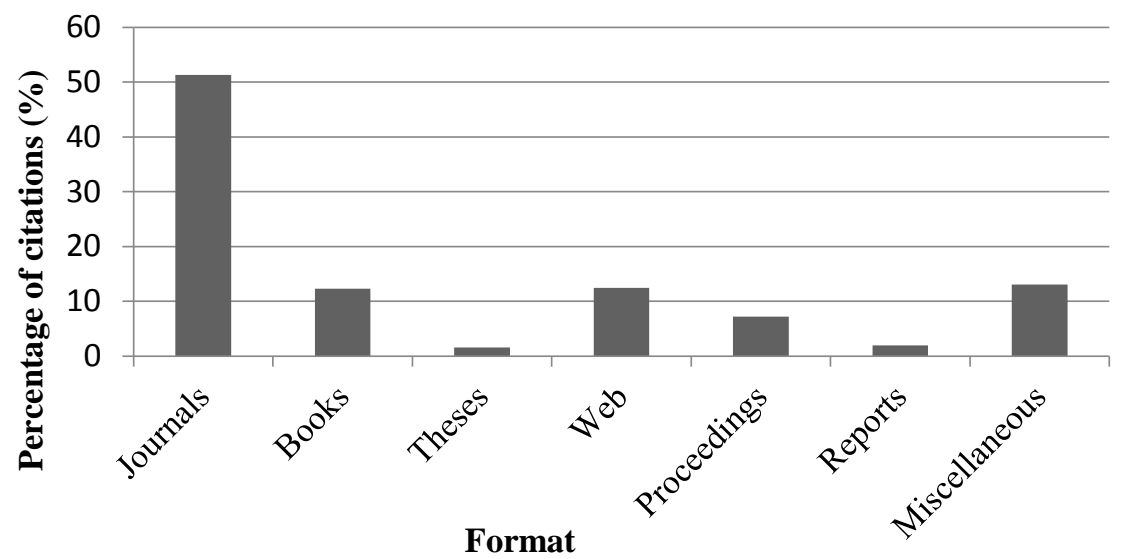

Figure 1: Distribution of the format of cited literature

\section{Application of the Bradford's law}

The total number of journal citations (412) was categorized into three approximately equal zones. Thirteen journals covered 139 citations while the next 58 journals covered 165 citations and the next 108 journals covered 108 citations respectively. According to Bradford zones, the relationship between each zone is 13:58:108. This data set does not fit into the Bradford's distribution (Tables 1 and 2).

Therefore the model developed by Leimkuhler was applied to verify the Bradford's law of scattering.

Number of groups $\mathrm{p}=3$ and the number of items in the most productive source $Y_{m}=17$.

Bradford multiplier $\mathrm{k}, \mathrm{k}=\left(\mathrm{e}^{\gamma} \mathrm{Y}_{\mathrm{m}}\right)^{1 / \mathrm{p}}$

$\mathrm{k}=(1.781 \times 17)^{1 / 3}=3.12$

The number of items in every Bradford group $\left(Y_{0}\right), Y_{o}=A / p=412 / 3=137$

Number of sources in the first Bradford group $\mathrm{r}_{\mathrm{o}}$ :

$\mathrm{r}_{\mathrm{o}}=\mathrm{T}(\mathrm{k}-1) /\left(\mathrm{k}^{\mathrm{p}}-1\right)=180(3.12-1) /\left(3.12^{3}-1\right)=13$

Therefore Bradford's distribution: 13:13(3.12):13(3.12 $\left.{ }^{2}\right)=13: 40.56: 126.55$

Percentage error $=\{((13+40.56+126.55)-180) / 180\} * 100 \%=0.06 \%$ 
Table 1: Distribution of Journals

\begin{tabular}{|c|c|c|c|c|c|c|c|}
\hline \multirow{3}{*}{ Rank } & \multicolumn{3}{|c|}{ Cumulative } & \multirow{2}{*}{$\begin{array}{l}\text { Total } \\
\text { no. of }\end{array}$} & \multirow{2}{*}{$\begin{array}{c}\text { Cumulative } \\
\text { no. }\end{array}$} & \multirow{3}{*}{$\log n$} & $(\%)$ \\
\hline & No. of & & No. of & & & & Cumulative \\
\hline & journals & (n) & citations & citations & of citations & & citations \\
\hline 1 & 1 & 1 & 27 & 27 & 27 & 0 & 6.553398058 \\
\hline 2 & 1 & 2 & 15 & 15 & 42 & 0.693 & 10.19417476 \\
\hline 3 & 1 & 3 & 13 & 13 & 55 & 1.099 & 13.34951456 \\
\hline 4 & 2 & 5 & 12 & 24 & 79 & 1.609 & 19.17475728 \\
\hline 5 & 2 & 7 & 10 & 20 & 99 & 1.946 & 24.02912621 \\
\hline 6 & 1 & 8 & 9 & 9 & 108 & 2.097 & 26.21359223 \\
\hline 7 & 1 & 9 & 7 & 7 & 115 & 2.197 & 27.91262136 \\
\hline 8 & 4 & 13 & 6 & 24 & 139 & 2.565 & 33.73786408 \\
\hline 9 & 6 & 19 & 5 & 30 & 169 & 2.944 & 41.01941748 \\
\hline 10 & 11 & 30 & 4 & 44 & 213 & 3.401 & 51.69902913 \\
\hline 11 & 9 & 39 & 3 & 27 & 240 & 3.664 & 58.25242718 \\
\hline 12 & 32 & 71 & 2 & 64 & 304 & 4.263 & 73.78640777 \\
\hline 13 & 108 & 179 & 1 & 108 & 412 & 5.187 & 100 \\
\hline
\end{tabular}

Table 2: Scattering of journals and citations over Bradford zones

\begin{tabular}{ccccc}
\hline Zone & $\begin{array}{c}\text { No. of } \\
\text { journals }\end{array}$ & $\begin{array}{c}\text { No. of } \\
\text { citations }\end{array}$ & $\begin{array}{c}\text { \% } \\
\text { journals }\end{array}$ & $\begin{array}{c}\text { \% } \\
\text { citations }\end{array}$ \\
\hline & & & & \\
1 & 13 & 139 & 7.263 & 33.738 \\
2 & 58 & 165 & 32.402 & 40.048 \\
3 & 108 & 108 & 60.335 & 26.214 \\
Total & 179 & 412 & 100 & 100 \\
\hline
\end{tabular}

The data set fits well with the Leimkuhler model of the Bradford's law since the percentage error is negligible. Therefore, in the first zone 13 journals, that is, the core journals (7.263 per cent) covered 133 citations (32.281 per cent), the next 40 journals (22.346 per cent) covered 133 citations (32.281) 
while the next 126 journals (70.391 per cent) covered 146 citations respectively (35.437 per cent) (Table 3 ).

Table 3: Scattering of journals and citations based on Leimkuhler model

\begin{tabular}{ccccc}
\hline Zone & $\begin{array}{c}\text { No. of } \\
\text { journals }\end{array}$ & $\begin{array}{c}\text { No. of } \\
\text { citations }\end{array}$ & $\begin{array}{c}\text { \% } \\
\text { journals }\end{array}$ & $\begin{array}{c}\text { \% } \\
\text { citations }\end{array}$ \\
\hline & & & & \\
1 & 13 & 133 & 7.263 & 32.281 \\
2 & 40 & 133 & 22.346 & 32.281 \\
3 & 126 & 146 & 70.391 & 35.437 \\
Total & 179 & 412 & 100 & 100 \\
\hline
\end{tabular}

The graphical distribution which is the "experimental verification of the verbal formulation which observes certain regularity in the distribution of scientific publications" (Sudhier, 2010, p.12) is presented in figure 2.

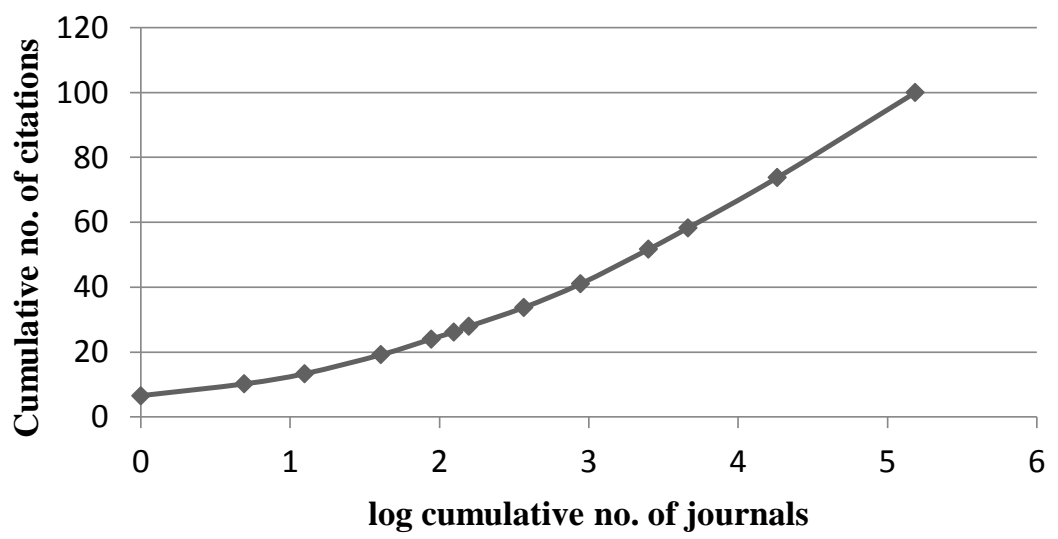

Figure 2 : Bradford plot for journal distribution

Ranked list of core journals is given in Table 4. 


\section{Table 4: Ranked list of Core journals (Journals in Bradford's Zone 1)}

\begin{tabular}{ccc}
\hline S/N & Journal name & Rank \\
\hline 1 & The Journal of Academic librarianship & 1 \\
2 & Journal of the University Librarians Association of Sri Lanka & 2 \\
3 & Library Review & 3 \\
4 & College and Research libraries & 4 \\
5 & Scientometrics & 4 \\
6 & Library Philosophy and Practice (e journal) & 5 \\
7 & Library Trends & 5 \\
8 & Journal of Marketing & 6 \\
9 & Information Research & 7 \\
10 & Collection Building & 8 \\
11 & New Library World & 8 \\
12 & Sri Lanka Library Review & 8 \\
13 & The Electronic Library & 8 \\
\hline
\end{tabular}

\section{Chronological distribution of cited material}

Table 5 reveals the number of citations scattered during the period from 1950 to 2015. For convenience the overall citations have been categorized into 8 groups, each comprising a time span of 10 years up to 2010 and followed by a span of 5 years, i.e. 2011 to 2015. According to Banateppanavar et al. (2015) this type of analysis indicates the growth of a discipline, over a period in terms of research output. Table 5 shows that Sri Lankan LIS researchers have mostly cited materials published during the time span of 2001-2010. 
Table 5: The Chronological distribution of cited material

\begin{tabular}{|c|c|c|c|}
\hline Publication year & $\begin{array}{c}\text { Number of } \\
\text { citations }\end{array}$ & \% of citations & $\begin{array}{c}\text { Cumulative } \\
\text { percentage }\end{array}$ \\
\hline $2011-2015$ & 109 & 13.57409714 & 13.57409714 \\
\hline $2001-2010$ & 407 & 50.68493151 & 64.25902864 \\
\hline $1991-2000$ & 156 & 19.42714819 & 83.68617684 \\
\hline $1981-1990$ & 45 & 5.603985056 & 89.29016189 \\
\hline $1971-1980$ & 27 & 3.362391034 & 92.65255293 \\
\hline $1961-1970$ & 19 & 2.366127024 & 95.01867995 \\
\hline $1951-1960$ & 11 & 1.369863014 & 96.38854296 \\
\hline 1950 and before & 13 & 1.618929016 & 98.00747198 \\
\hline no date & 16 & 1.99252802 & 100 \\
\hline Total & $\mathbf{8 0 3}$ & & \\
\hline
\end{tabular}

\section{Categorization of articles into subject domains}

The articles were categorized into subject domains within LIS following the classification scheme of LIS topics, devised by Jarvelin \& Vakkari (1990). This is presented in table 6. It shows that most of the articles belong to "information seeking" field of LIS research. This field included articles on user studies, the use of library services, information seeking behavior and information management.

Table 6: Subject-wise distribution of articles

\begin{tabular}{|l|l|l|}
\hline Main fields of LIS research & $\begin{array}{l}\text { No. of } \\
\text { articles }\end{array}$ & $\begin{array}{l}\text { Percentage } \\
\text { of articles }\end{array}$ \\
\hline The professions in the field of LIS & 3 & 6.5232 \\
\hline Library History & 2 & 4.348 \\
\hline Publishing (includes book history) & - & 0 \\
\hline Education in LIS & 3 & 6.522 \\
\hline Methodology/analysis of LIS & - & 0 \\
\hline Library and information service activities & 8 & 17.391 \\
\hline Information storage and retrieval & 7 & 15.216 \\
\hline Information seeking & 15 & 32.609 \\
\hline Scientific communication & 6 & 13.044 \\
\hline Other aspects of LIS & 2 & 4.348 \\
\hline Total & $\mathbf{4 6}$ & $\mathbf{1 0 0}$ \\
\hline
\end{tabular}




\section{Conclusion}

The study shows that journals were the most widely used resource type by LIS academics in Sri Lanka, for their research purposes. This result is in agreement with many previously conducted citation studies (Banateppanvar et al., 2013; Trigar et al., 2013; Chikate \& Patil, 2008; Kuri \& Hajje, 2014). In testifying the Bradford's law, data sets were fit with the Leimkuhler model of the Bradford's law. This model was used to determine the core journals in the Sri Lankan LIS field. It was revealed that "The Journal of Academic Librarianship" was the highly preferred journal for scholarly communication by Sri Lankan LIS researchers. Other than that, international journals such as Library Review, Scientometrics, College and Research Libraries, Library Philosophy and Practice and Library Trends were also widely used by LIS researchers. Based on the results, indicators can be built in support of the LIS collection development in Sri Lankan libraries. Librarians can select "core journals" that are vital and of greater productivity to include into their library collection. Priority for subscriptions should be given to these core journals. If there are financial limitations least cited journals can be considered for cancellation.

The chronological distribution of cited material demonstrates that the LIS researchers have mostly utilized material published within 2001-2010. It also shows that material published before 2001 is less used. This study confirms the need of acquiring material published after 2000, into LIS collections in Sri Lankan libraries in order to satisfy their user needs. The subject trends in articles of the JULA shows that the field of "information seeking" is the most popular area of research among Sri Lankan LIS researchers. So, it can be recommended to include material such as books and journals relating to the subject area of "information seeking" into library LIS collections. This study can be further improved by considering inter library loan requests, identifying subject-wise distribution of all citations and conducting interviews with the library collection users in order to gain more insight into developing the collection in a user-centric manner. 


\section{References}

Ahmed, O. S., Osinaike, A. B. (2010). Citation analysis of Journal of Library and Information Science (2004-2009). Brazilian Journal of Information Science, 4(1), 35-60. Retrieved from http://www.bjis.unesp.br/ojs2.4.5/index.php/bjis/article/download/482/589.

Angammana, A.M.S., Jayatissa, L.A., (2016). A bibliometric study of postgraduate theses in library and information science: With special reference to University of Kelaniya and University of Colombo, Sri Lanka. Journal of the University Librarians Association of Sri Lanka, 19(1), 32-53. doi: 10.4038/jula.v19i1.7874.

Banateppanvar, K., Biradar, B.S., Kannappanavar, B.U. (2013). Citation analysis of doctoral theses in Biotechnology submitted to Kuvempu University, Karnataka: A case study. International Journal of Information Dissemination and Technology, 3(3), 147-157. Retrieved from http://www.ijidt.com/index.php/ijidt/article/viewFile/178/175.

Banateppanavar, K., Dharanikumar, P., Vindya, A. B. (2015). Bradford's zone to LIS publications published in Collection Building journal from 2009-2012: A citation study. Collection Building, 34(2), 6574. doi: $10.1108 / \mathrm{cb}-01-2014-0011$.

Barnett-Ellis, P., Tang, Y. (2016). User-Centered collection development: A citation analysis of graduate Biology theses. Collection Management, 41(1), 3-22. doi : 10.1080/01462679.2016.1145088.

Bradford, S.C. (1950). Documentation. Washington; Public Affairs Press.

Chikate, R. V., Patil, S. K. (2008). Citation analysis of theses in library and information science submitted to University of Pune: A pilot study. Library Philosophy and Practice (e-journal). Retrieved from http://digitalcommons.unl.edu/cgi/viewcontent.cgi?article=1224\&co ntext=libphilprac.

Egghe, L. (1986). The dual of Bradford's law. Journal of the American Society for Information Science, 37(4), 246-255. 
doi:10.1002/(sici)1097-4571(198607)37:4<246::aid-asi10>3.0.co;2-.

Egghe, L. (1990a). A note on different Bradford multipliers. Journal of the American Society for Information Science, 41(3), 204-209. doi: 10.1002/(sici)1097-4571(199004)41:3<204::aid-asi7>3.0.co;2-8 .

Egghe, L. (1990b). Applications of the theory of Bradford's law to the calculation of Leimkuhler's law and the completion of bibliographies. Journal of the American Society for Information Science, 41(7), 469-492. doi: 10.1002/(sici)10974571(199010)41:7<469::aid-asi1>3.0.co;2-p.

Gunasekera, C.(2014). Citation analysis of masters theses: As a tool for collection development in academic libraries. Journal of the University Librarians Association of Sri Lanka. 17(2), 88-103. doi: 10.4038/jula.v17i2.6647.

Gunasekera, C.(2008). Library and information sciences research literature in Sri Lanka: A bibliometric study. Journal of the University Librarians Association of Sri Lanka. 12.17-46. doi: 10.4038/jula.v12i0.327.

Hoffmann, K., Doucette, L. (2012). A review of citation analysis methodologies for collection management. College \& Research Libraries, 73(4), 321-335. doi : 10.5860/crl-254.

Jarvelin, K., Vakkari, P.(1990). Content analysis or research articles in library and information science. Library and Information Science Research, 12 (4), 395-421.

Kuri, R., Hajje, V. (2014). Citation Analysis of Pearl: A Journal of Library and Information Science. Asian Journal of Multidisciplinary Studies, 2(9), 8-13.Retrieved from http://ajms.co.in/sites/ajms2015/index.php/ajms/article/viewFile/488 $\underline{1526}$.

Leimkuhler, F. F. (1980). An exact formulation of Bradford's law. Journal of 
Documentation, 36(4), 285-292. doi : 10.1108/eb026699.

Navaneethakrishnan, S., Kupesan, R. (2015). Bibliometric analysis of Sri Lanka Journal of the Humanities. Journal of the University Librarians Association of Sri Lanka. 18(1), 51- $71 . \quad$ doi: $\underline{10.4038 / j u l a . v 18 i 1.7861}$

Pritchard, A. (1969). Statistical bibliography or bibliometrics. Journal of Documentation, 25(4), 348-349.

Rosenberg, Z. (2015). Citation analysis of MA theses and Ph. D. dissertations in Sociology and Anthropology: An assessment of library resource usage. The Journal of Academic Librarianship, 41(5), 680-688. doi : 10.1016/j.acalib.2015.05.010.

Simisaye, A. O., Osinaike, A. B. (2011). Citation analysis of Journal of Library and Information Science (2004-2009). Brazilian Journal of Information Science: Research Trends, 4(1), 37-63. Retrieved from http://www.bjis.unesp.br/ojs2.4.5/index.php/bjis/article/download/482/589.

Singh, K. P., Bebi, M. (2013). Citation analysis of PhD theses in Sociology submitted to University of Delhi during 1995-2010. DESIDOC Journal of Library \& Information Technology, 33(6), 488-492. doi : 10.14429/djlit.33.5480.

Sudhier, K.G. (2010). Application of Bradford's law of scattering to the physics literature: A study of doctoral theses citations at the Indian Institute of Science. DESIDOC Journal of Library \& Information Technology, 30(2), 3-14. doi : 10.14429/djlit.30.3.

Trigar, A., Abolghasemi, M.B., \& Yaminfrooz, M. (2013). Citation analysis of graduate Dental thesis references: Before and after an intervention. Future of Medical Education Journal, 3(1), 1-7. doi: 10.22038/fmej.2013.515. 
Wardikar, V.G. (2013). Application of Bradford's law of scattering to the literature of library \& information science: A study of doctoral theses citations submitted to the Universities of Maharashtra, India. Library Philosophy and Practice (e-journal). Retrieved from http://digitalcommons.unl.edu/cgi/viewcontent.cgi?article=2569\&con text=libphilprac.

Zafrunnisha, N. (2012). Citations in the sociology doctoral dissertations: A quantitative analysis. International Journal of Information Dissemination and Technology, 2(3), 212-218. Retrieved from http://ijidt.com/index.php/ijidt/article/download/100/100. 